folk/ed. Derg, 2022; 28(1)-109. sayı

DOI: $10.22559 /$ folklor.1787

Araştırma makalesi/Research article

\title{
Çok Anlamlılıktan Eş Adlııı̆a Doğru Tarihsel Bir Yolculuk
}

\section{A Historical Travel from Polysemy to Homonym}

$\ddot{O} z$

$\mathrm{Bu}$ çalışmada, aynı kökene dayanan çok anlamlı ve aynı kökene dayanan sözcüklerin tarihsel yolculukları içinde anlam genişlemelerinden kaynaklı sözlük birimlerinin birbirinden uzaklaşmasıyla eş adlı duruma gelme süreçleri incelenmiştir. Eş adlılar; sesleri ve yazılışları aynı, anlamları farklı olan sözcükler olarak tanımlanmaktadır. Çok anlamlılık ise bir sözcügün birden fazla anlamı karşılamasıdır. Çok anlamlı sözcüklerde tek kök, birden fazla, birbiriyle ilintili anlam(lar), söz konusuyken eş adlı sözcüklerdeyse birbirinden farklı en az iki kök ve anlamlar söz konusudur. Türk Dil Kurumu Türkçe Sözlük'ten genel tarama modeliyle elde edilen fişılenen acımak, ağıl, ağız, ağmak, altıparmak, basılmak, biçim, bir bir, bitmek, boy, bozuk, çakmak, çil, çöğür, dayak, dikilmek, dikmek, dil, dokunma, dokunmak, dokunuş, el, gen, güç, günlük, öz, sağ, sormak, ters, terslemek, uçuk, uğur, uz, yaş, yaşlı, yazı, yazmak, yordurmak, yormak, yorulmak sözcüklerinin çok anlamlılıktan eş adlığa doğru tarihsel bir yolculuk yaptıkları tespit edilmiştir.

Geliş tarihi (Received): 30-03-2021 - Kabul tarihi (Accepted): 4.01.2021

* Dr. Öğr. Üyesi. Mardin Artuklu Üniversitesi Edebiyat Fakültesi Türk Dili ve Edebiyatı Bölümü (Mardin Artuklu University Faculty of Letters Department of Turkish Language and Literature) Turkey. hadraerkinay@hotmail. com. ORCID 0000-0003-1469-0404 
Sözlükte eş adlı sözcükler, (I) (II) (III) Romen rakamlarıyla birden fazla madde başında gösterilmiştir. Çok anlamlı sözcüklerin genişlemiş anlamları ise tek madde başında 1, 2, 3 rakamlarıyla gösterilmiştir. Türkçe Sözlük’ten tespit edilen 40 eş adlı sözcüğün -etimolojik ve tarihî sözlüklerden yola çıkılarak- aslında kökeni aynı olan çok anlamlı sözcükler olduğu ve anlam genişlemeleri yoluyla sözlük birimlerinin birbirinden uzaklaşarak tarihsel yolculukları içinde eş adlı duruma geldiği belirlenmiştir.

Anahtar sözcükler: çok anlamlılık, eş adlılık, anlam genişlemesi, Türkçe Sözlük, köken bilimi

\begin{abstract}
In this study, the process of becoming homonym due to the expansion of meaning within the historical journey of polysemy, which are actually very meaningful and based on the same origin, in the Turkish Dictionary of the Türk Dil Kurumu, was examined. Homonym; it is defined as words whose phone and spelling are the same and their meanings are different. In polysemy words involve more than one meaning. While there is a single origin in polysemy words, there are more than one but related meanings, in homonyms, there are at least two different origins and different meanings from each other. Tagged with the general scanning model in the Turkish Dictionary, acımak, ăğl, ăglz, ăgmak, altıparmak, basılmak, biçim, bir bir, bitmek, boy, bozuk, çakmak, çil, çöğür, dayak, dikilmek, dikmek, dil, dokunma, dokunmak, dokunuş, el, gen, güç, günlük, öz, sağ, sormak, ters, terslemek, uçuk, uğur, uz, yaş, yaşll, yazl, yazmak, yordurmak, yormak, yorulmak have turned into polysemy from homonym. In the spelling of homonyms in the dictionary, to two separate lexical entry and (I) (II) (III) Roman numerals form besides homonyms is preferred. Expanded meanings of polysemys are shown with the numbers 1,2 , and 3 at the beginning of generally prioritizing the basic meaning. Based on the etymology and historical dictionaries of the determined 40 words, it has been determined that the dictionary units of the polysemy words with the same origin are decomposed through the expansion and change of meaning over time and become polysemy.
\end{abstract}

Keywords: polysemy, homonym, semantic extension, Turkish Dictionary, etymology

\title{
Extended summary
}

Polysemy, is the fact of having more than one meaning. There are various ways and causes of polysemy. Homonym is words whose pronounced have the same meanings. In other words, homonym means one of two or more words that have the same sound and often the same spelling but differ in meaning.

The homonym is the same in sound and spelling, but differ in origin and meaning. Polysemy words have emerged with the same word gaining different meanings in the language, usually through metaphor, metonymy. In homonym, there is no relationship 
between the phonetic signs in terms of meaning, while there is definitely a relationship between the different meanings of the same word in polysemy. Homonym and polysemy are often confused because they are close relationship situations. There is confusion in some terms and concepts related to semantics in Turkish. In some terms, a unity has not yet been reached in Turkish. In addition to this, terms translated from foreign languages, especially French, into Turkish also leads to term confusion. However, there are curriculum differences between the YÖK and the MEB. It is seen that terms are intertwined and generally used interchangeably. However, while some of these terms are the same, there is only a connection between some of them. In other words, homonym includes the homophony and homography. The new terms (for example: eş biçimlilik, eş gösterenlik) have recently begun to be preferred in the literature. In addition to the confusion between these terms, when the issue of polysemy is added, a greater uncertainty arises. In this study, it was determined that the homonym and polysemy terms, although they are different from each other, have been passed from one to another in their historical travel. From the Old Turkish to the Turkey Turkish 40 words made a historical travel and changed.

In fact if the meanings of the concepts are related, they are polysemy; If it is unrelated, it is homonym. With the dissociate of lexeme in polysemy words, there is a transition to homonym. The relationship between the meanings of polysemy words go away from each other, and homonym emerge by meeting a separate word for each meaning. This process takes place as a result of a historical travel.

General scanning model, one of the scanning models, was used in the research. It has been determined that the reason for the formation of 40 of the 641 homonyms with the same spellings in the Turkish Dictionary is due to polysemy. Origins and meanings of homonym determined by scanning from etymological and historical dictionaries for example, Clauson (1972), Eren (1999), Tietze (2002), Tietze (2009), Eyuboğlu (2017), Nişanyan (www. nisanyansozluk.com), Tarama Sözlüğ̈̈, Derleme Sözlüğ̈̈. It has been observed that the homonym given different lexical entries in the Turkish Dictionary are actually based on the same origin in historical processes and they are polysemy. Tagged with the general scanning model these words in the Turkish Dictionary, acımak, ăgll, ăgız, ăgmak, altiparmak, basllmak, biçim, bir bir, bitmek, boy, bozuk, çakmak, çil, çöğür, dayak, dikilmek, dikmek, dil, dokunma, dokunmak, dokunuş, el, gen, güç, günlük, öz, sağ, sormak, ters, terslemek, uçuk, uğur, uz, yaş, yaşll, yazl, yazmak, yordurmak, yormak, yorulmak have turned into polysemy from homonym. In the spelling of homonyms in the dictionary, to two separate lexical entry and (I) (II) (III) etc. Roman numerals form besides homonyms is preferred. Expanded meanings of polysemys are shown with the numbers 1,2 , and 3 at the beginning of generally prioritizing the basic meaning. Based on the etymology and historical dictionaries of the determined 40 words, it has been determined that the lexeme of the polysemy with the same origin are decomposed through the expansion and change of meaning over time and become polysemy.

In the Turkish Dictionary, 40 words were identified with the general scanning model which were itemized as lexeme with homonym. It has been determined that these data, by using historical and etymological dictionaries, have passed from polysemy situation to a 
homonym due to some changes in meaning and expansion throughout their historical travel. In fact, these 40 words are the versions of the meaning units of the word belonging to the same origin that diverged from each other over time and formed new dictionary units. Polysemy and homonym are also intertwined in other languages, such as the Turkish language. One of the reasons for the formation of polysemy and homonym is the another one. In this context, it would be appropriate to say that the reasons for the formation of some homonyms in Turkish vocabulary are due to polysemy.

\section{Giriş}

Türkçede anlam bilimiyle ilgili birtakım terim ve kavramlarda karmaşa yaşanmaktadır. Bazı terimlerde hâlen birliğe varılmamıştır. Terim birliği haricinde yabancı dillerden, özellikle Fransızcadan, Türkçeye çevrilen bazı terimlerin tam karşılığının olmaması da terim karışıklığına yol açmaktadır. Bununla birlikte Yükseköğretim Kurumu ile Millî Eğitim Bakanlığı arasında müfredat farklılıkları bulunmaktadır. Ayrıca orta öğretim ve lisans düzeyindeki konu işleyişlerinin kimi zaman hatalı olduğu görülmektedir. Eş adlılık, eş yazımlılık, eşseslilik/sesteş, eş biçimlilik, eş gösterenlik, eş işlevlilik konularının müfredatlarda bir belirsizlik ve kargaşa içinde olduğu ve bu kavramların genellikle birbirinin yerine kullanıldığı görülmektedir. Oysaki bu terimlerin kimisi aynı, kimisi farklı olup kimisi arasında sadece belirli bağlantılar vardır. Örneğin, eş sesli-sesteş terimleri aynı kavramı karşılarken eş adlılık; eş yazımlılık ve eş seslilik başlıklarını kapsamaktadır. Yani eş adlı büyük bir küme ve bu kümenin içinde eş seslilik ve eş yazımlılığı içeren iki ayrı küçük küme tasavvur edilmesi mümkündür. Eş biçimlilik ve eş gösterenlik terimleriyse literatürde son zamanlarda eş adlılık terimini karşılamak üzere tercih edilmeye başlanmıştır.

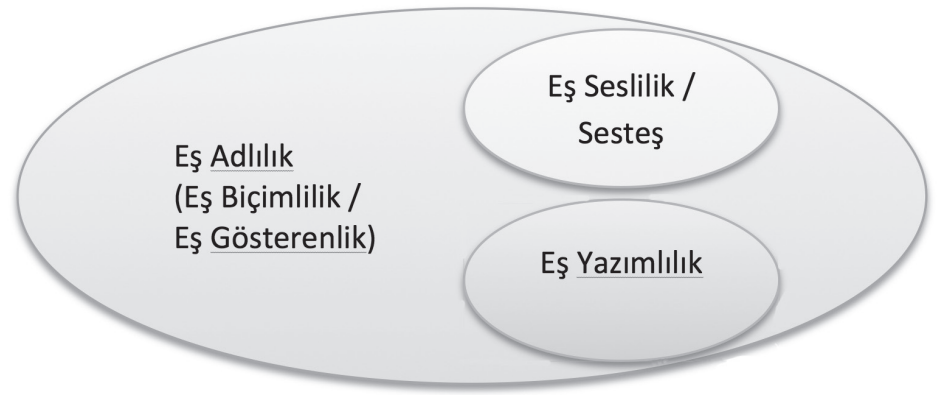

Şekil 1. Eş Adlılık ve Alt Kümeleri

Bu kavramlar arasındaki ilişkiyi aynı zamanda mantıktaki tam girişimlikle açıklamak mümkündür. Kavramlardan yalnız birinin diğerinin tüm bireylerini içine alma durumu olarak açıklanan tam girişimliğe göre 'Bazı hayvanlar kuştur.' ve 'Bütün kuşlar hayvandır' önermeleri söz konusudur (Akıncı ve Ünder, 2013: 17). Bu önermeler dil bilimine 'Bazı eş adlılar eş seslidir.', 'Bazı eş adlılar eş yazımlıdır.', 'Bütün eş yazımlılar eş adlıdır.' ve ‘Bütün eş sesliler eş adlıdır.' biçiminde uyarlanabilir. 
Bu terimler arasındaki kargaşanın yanı sıra çok anlamlılık, eş anlamlılık, yakın anlamlılık mevzusu da işin içine girince ortaya daha büyük bir belirsizlik çıkmaktadır. Özellikle bazı sözlük hazırlayıcıları madde başlarında eş adlı ve çok anlamlı sözcükleri birbirine karıştırmaktadır. Kimi eş adlı sözcükler, sözlüklerde ayrı madde başı olması gerekirken tek madde başı ve çok anlamlı olarak verilmektedir. Bu karışıklığın nedenlerinden biri, tarihî süreç içerisinde bu kavramların birinin, bir diğerine dönüşmesidir. Kimi çok anlamlı sözcüklerin ise leksik birimlerinin zayıflaması vd. etkenlerden dolayı sözlüklerde ayrı madde başlarında eş adlı durumda oldukları dikkat çekmektedir (Erkınay Tamtamış, 2021: 641). Bu çalışmada, art zamanlı bir incelemeyle 40 çok anlamlı sözcüğün gerçekleştirdikleri tarihsel yolculukları içinde eş adlı duruma geçişleri incelenmiştir.

\section{Çok anlamlılık ve eş adlılık}

Çok anlamlılık, bir sözcüğün birden fazla anlamı karşılaması durumudur. Bir dildeki tek bir gösterenin birden çok gösterileni olması durumu (Günay, 2007: 188), bir sözcük veya sözcük öbeğinin farklı anlamları arasında edindiği ilişki (Hartmann ve James, 1998: 110), aynı sözcügün farklı farklı anlamlara sahip olma durumudur (Palmer, 2001: 82).

Eş adlılık, söylenişi ya da yazılışı aynı, anlamları farklı sözcüklerdir. Yani bu sözcüklerin ses yapısı ortaktır. İki ya da daha çok kavramın ses ya da yazım açısından aynı göstergelerle dile getirilmesidir (Üçok, 2004: 96; Ahanov, 2008: 110; Hengirmen, 2009: 158; İmer vd., 2011: 118).

Eş adlı sözcükler ses ve yazım açısından aynıyken köken ve anlam bakımından farklıdır. Çok anlamlı sözcükler ise aynı sözcüğün dilde genellikle eğretileme yoluyla farklı anlamlar kazanması ile ortaya çıkmıştır (Toklu, 2003: 94). Çok anlamlılıkta sözcüğün kökeni aynı, anlamları farklı ama birbirleriyle genelde bağlantılıyken; eş adlılıkta hem sözcüklerin kökeni hem anlamları birbirinden farklıdır. "Eş adlılarda, sesçe aynı olan göstergeler arasında anlam açısından hiçbir ilişki bulunmazken çokanlamlılıkta aynı sözcüğün değişik anlamları arasında mutlaka bir ilişki vardır” (Aksan, 2009: 192-193). Eş adlı sözcüklerin anlamları arasında ilişki bulunmasının nedeni sözcük kökenlerinin birbirlerinden farklı olmasıdır. Çok anlamlılıkta ise aynı sözcük, anlam genişlemesi yoluyla çeşitli anlamlar kazandığından dolayı anlamlar arasında benzerlik, aktarma gibi ilişkiler söz konusudur. Eş adlılığın nedenleri daha ciddi ve çarpıcı olmasına rağmen çok anlamlılığa göre daha az karmaşıktır. Eş adlılığın nedenleri fonetik yakınlık, eş adlı sözcüklerin çatışmaları ve yabancı etkilerdir (Ullmann, 1970: 176-180).

Bir dildeki sözcüklerin anlamsal olarak ele alınmasında eş adlılık / çok anlamlılık özellikleri göz önünde bulundurulabilir; zira bu tür anlamsal olaylar her dilde vardır. Türkçedeki yüz sözcüğünün anlamları düşünüldüğünde çok anlamlılıktan, bir başka açıdan düşünüldüğünde eş adlılıktan söz edilebilir (Günay, 2007: 187). Yüz sözcüğü Türkçe Sözlük'te iki ayrı madde başı yüz (I) ve yüz (II) olarak kayıtlıdır (TS, 2011: 2630). O halde Türkçe Sözlük'e göre yüz sözcüğü eş adlıdır. Bununla birlikte sözcüğün her madde başında birden fazla anlamının olması sözcüğün eş adlı olmasının yanı sıra çok anlamlı olduğunun da göstergesidir. 
Eş adlılık iki farklı sözcükmüş gibi sesletilen veya yazılan, aynı anlama sahip olmayan iki ya da daha fazla sözcük arasındaki ilişkiyi belirtmektedir. Eş adlı sözcüklerin kökenleri genellikle farklılık arz etmektedir. Eş adlılıkta başlangıçta ayrı olup sonradan ses değişimi veya başka etkenlerin sonucu aynı biçime bürünmüş sözcükler söz konusuyken çok anlamlılıkta aynı adın zamanla birçok anlama gelmesi durumu söz konusudur (Günay, 2007: 200). Eş adlılığın, iki farklı sözcükmüş gibi sesletilen veya yazılan ibaresinden de yola çıkılarak eş seslilik ve eş yazımlılık kavramlarını kapsadığı görülmektedir. Bir sözcüğün yazımlarının veya sesletimlerinin aynı, anlamlarının farklı olması sözcüğü, eş adlı yapmaktadır. Söylenişi aynı, yazılışı ayrı eş adlı sözcüklere eş sesli, yazılışı aynı, söylenişi ayrı eş adlı sözcüklere eş yazımlı denmektedir. Bu durum kimi dillerde (örneğin Fransızca) görülmektedir (Günay, 2007: 200). Her hâlükârda eş sesli ve eş yazımlı sözcüklerin her biri eş adlıdır. Türkçe sesçil bir alfabeye sahip olduğundan Türkçede eş seslilik ya da eş yazımlılık olgusu bulunmamaktadır. Türkçe açısından aynı biçimde yazılan veya söylenen sözcükler için farklı anlamlı eş seslilik ve eş yazımlılıktan söz edilebilinir. Bu durumda Türkçede eş sesli, eş yazımlı ve eş adlı sözcükler aynı durumu belirtmektedir (Günay, 2007: 204). Eş adlılık her iki kavramı da kapsayıcı bir özellik göstermektedir.

\section{Çok anlamlılıktan eş adlılığa geçiş}

Dillerin ses ve anlam yapılarının sürekli değişmesi, çok anlamlılıktan eş sesliliğe, eş seslilikten çok anlamlılığa doğru sürekli bir geçişin kapısını aralamaktadır. Eş seslilik ve çok anlamlılık birbirini izleyen durumlar olduğu için sık sık karıştırılır. (Karaağaç, 2013: 216-217).

İki kavramın birbirlerinden anlam ve köken farklılıklarıyla ayırt edilmesi mümkündür. Kavramların anlamları birbirleriyle ilişkiliyse çok anlamlılık; ilişkili değilse eş adlılık söz konu-sudur. Çok anlamlı sözcüklerde leksik birimlerin zayıflamasıyla eş adlılığa geçiş olmaktadır. Çok anlamlı sözcüklerin anlamları arasındaki ilişkinin zamanla zayıflaması sonucu her an-am ayrı bir sözcüğü karşılayarak eş adlılık ortaya çıkmaktadır.

Araştırmada tarama modellerinden genel tarama modeli kullanılmıştır. Genel tarama modeli, çok sayıda elamandan oluşan evrende, evren hakkında geniş bir yargıya varmak amacıla evrenin tümü ya da örneklem üzerinden yapılan tarama düzenlemeleridir (Karasar, 2012: 77-79). Türkçe Sözlük'teki -eş adlı sözcükleri belirleme stili olan ayrı madde başlarında, Romen rakamlarıyla belirtilmiş, yazılışları aynı- 641 eş adlı sözcükten 40 tanesinin çok anlamlılıktan kaynaklı olduğu tespit edilmiştir. Eş adlı sözcüklerin kökenleri ve anlamlar1; Clauson (1972), Eren (1999), Tietze (2002), Tietze (2009), Eyuboğlu (2017), Nişanyan (www.nisanyansozluk.com), Tarama Sözlüğü, Derleme Sözlüğü taranarak belirlenmiştir. Türkçe Sözlük’te ayrı madde başlarında verilen eş adlıların, aslında tarihî süreçlerde aynı kökene dayanıp çok anlamlı durumda oldukları görülmüştür. Oysaki eş adlılıktan beklenen, farklı köken ve bağlantısız anlamlardır. Çok anlamlı olan sözcükler zamanla anlam ayrışmasına uğramış, her bir anlam birimi ayrı sözlük birimi durumuna gelmiştir.Türkçe Sözlük’te çok anlamlılıktan eş adlılığa doğru tarihsel yolculuk yapan 
sözcükler şunlardır: acımak (I) (II) (III); ăğl (I) (II); ăğz (I) (II); ağmak (I) (II); alttparmak (I) (II); basllmak (I) (II); biçim (I) (II); bir bir (I) (II); bitmek (I) (II); boy (I) (II) (III); bozuk (I) (II); çakmak (I) (II); çil (I) (II) (III); çöğür (I) (II); dayak (I) (II); dikilmek (I) (II); dikmek (I) (II); dil (I) (II) (IV); dokunma (I) (II); dokunmak (I) (II); dokunuş (I) (II); el (II) (III); gen (I) (II); gü̧̈ (I) (II); günlük (I) (II); öz (I) (II); săg (I) (II); sormak (I) (II); ters (I) (II); terslemek (I) (II); uçuk (I) (II); uğur (I) (II) (III); uz (I) (II); yaş (I) (II); yaşlı (I) (II); yazı (I) (II); yazmak (I) (II); yordurmak (I) (II); yormak (I) (II); yorulmak (I) (II).

\section{acımak (I) (II) (III)}

Türkçe Sözlük’te (2011: 11) üç ayrı madde başı olarak verilen sözcüğün anlamları şu şekilde kaydedilmiş̧ir: acımak (I) 'tadı acı duruma gelmek, acılaşmak'; acımak (II) 'acılı, ağrılı olmak'; acımak (III) '1.Merhamet etmek, 2. Başkasının uğradığı veya uğrayacağı kötü bir duruma üzülmek'. ael köküne eylemden eylem yapma eki '-t'nin getirilmesiyle türetilen acıtmak eylemi (TS' 1 2011: 12) ise acımak eylemindeki anlamları içermesine karşın (1. Acılık vermek; 2. Ağrı, sızı duyulmasına sebep olmak) tek madde başı olarak verilmiştir. ac1- < aç1- sözcüğü aslında 'fiziksel duyu anlamında acı olmak' anlamındayken sonrasında çok erken bir tarihte aynı zamanda 'ekşi, buruk olmak' gibi birkaç metaforik anlam geliştirilmiştir. En yaygın, bilinen anlamı 'hastalık vb. durumlarda acı verici olmak' bundan dolayı '(kişi) acı hissetmek' ve bunun sonucu olarak 'başkalarının acısını hissetmek; şefkat, acıma, merhamet duymak' anlamları ortaya çıkmış olup çoğu lehçede orijinal anlamı olan fiziksel anlamı kaybolmuştur. Osmanlı Türkçesi döneminde $a \check{g} F l$ derin ağrıyı ifade etmekte; ael yüzeysel ancak daha şiddetli, kalııı ağrı ve slz- gidip gelen kas veya sinir ağrısı anlamlarında kullanılmaktadır. Karahanlı Türkçesi döneminde eylem sirke açıdı 'sirke ekşidi, mayhoş oldu, keskinleşti' anlamında kullanılmıştır (Clauson, 1 972: 21). Uygur Türkçesi döneminde de buna benzer 'ekşi, acımtırak ve acı ızdırap' anlamları aynı madde başında verilmiştir: $a c ̧ ı \dot{g}$ (Caferoğlı2011: 2). Eyuboğlu (2017: 6) eylemin 'acı duymak, kendi özünde bir açıklık, çözülmüşlük sezmek' anlamlarının yanı sıra anlam geniş̧lemesiyle 'birine karşı eğilim duymak, yönelmek, yardımcı olmayı düşünmek' anlamlarını kazandığını belirtmiştir. Sözcük herhangi bir şeyin verdiği acıllk, tat alma duyusunun önce duyular arası anlam aktarmasıyla fiziksel acı duymak daha sonra somut anlamdan soyut anlama geçişle birine merhamet etmek anlamlarını kazanmış, çok anlamlılık ortaya çıkmıştır. Çok anlamlı duruma gelen sözcügü̈n anlamlarının her biri ayrı eş adlı duruma gelip madde başı biçiminde yazılmıştır.

\section{ağıl (I) (II)}

Türkçe Sözlük’te, ağıl (I) ‘Evcil küçükbaş hayvanların barındığı çit veya duvarla çevrili yer, arkaç’ ağıl (II) '1. Hale. 2. Bazı görüntülerdeki çok ışıklı cisimleri çevreleyen 1şıklı teker.' (TS, 2011: 40) anlamlarında olan sözcük Clauson'da tek madde başında kayıtlıdır. Clauson'a göre (1972: 83) sözcük başlangıçta 'çiftlik hayvanları için bir çevrilmiş yer; sığır 
ağıl1, koyun ağılı' anlamlarına gelmektedir. Bu yüzden 'çevrilmiş, kuşatılmış yer' anlamı ile bağlantılı olarak 'bir yerleşim yeri veya çadırlar grubu' anlamını kazanmıştır. Oğuzlarda 'koyun gübresi' anlamına da gelmektedir; ikisinin birbiriyle yakından bağlantısı vardır, tıpk1 Arapçadaki yağmur ve bulut sözcüklerinin her ikisinin sema sözcügüyle karşılanması gibi. 15. yüzyıl Çağatay Döneminden itibaren ağıl sözcüğü 'ayın etrafindaki hale' anlamıyla kullanılmaya başlanmıştır. Kuşatma, çevreleme anlamı ile sığırların içinde uyuması için yapılan çevrilmiş yer aynı anlam alanına aittir. Sözcük, aynı zamanda Farsça ve Sanskritçede kullanılmaktadır.

Eren (1999: 3) çağdaş lehçelerde $a \breve{g}_{l} l$ nn yanı sıra kullanılan ayll biçiminin Moğolcadan alıntılandığını bildirmiş, ăğl sözcüğünün ise kökeninin bilinmediğini belirtmiştir. Clauson (1972: 83) erken dönemde Moğolcada olan ayil sözcüğ̈nün, kuzey ve kuzeydoğu lehçelerinden yeniden ödünç alındığını belirtmiştir.

Türkçe Sözlük’te iki ayrı madde başı üç anlamla kaydedilen eş adlı sözcüğün aslında 'çevrelemek, bir şeyi daire içine almak, halkayla belirlemek, kuşatmak' anlamlarından yola çıkılarak anlam genişlemesi yoluyla çok anlamlı duruma geldiği söylenebilir.

\section{ağız (I) (II)}

Türkçe Sözlük’te iki ayrı madde başı olarak verilen sözcüğün ağız (II) 'yeni doğurmuş memelilerin ilk sütü' madde başı Orta Türkçede ağuz olarak geçmektedir. Kaşgarlı Mahmut ă̆uz yanında ă̆uj biçimini vermiş̧ir. Eski Kıpçakçada awuz biçimi de vardır (Clauson, 1972: 98; Tietze, 2002: 9; Eren, 1999: 5). Akar (2019: 28) ağız (II) madde başını ağız (I) madde başıyla (TS, 2011: 44) şu şekilde ilişkilendirmiştir: Yeni doğuran insan ve hayvanların ilk sütü, doğumdan hemen sonra meme uçlarında bulunan, bileşimi, görünüşü ve tadı normal sütten farkll, besleyici değeri yüksek, Türkçe tıp literatüründe ağlz sütü olarak geçmektedir. Sözcük bir şeyin başlangıç tarafi anlamındaki ağız sözünden gelişmiş olmalıdır: yolun ăgzl, tünelin ăgzl, ırmağın ağzl ... tamlamaları da bir mekânın başlangıclnı göstermektedir. Bu sözcükte de canlıların doğurduktan sonra göğüslerindeki başlangıç sütü ifade edilmektedir.

\section{ağmak (I) (II)}

Türkçe Sözlük’te (2011: 50) iki madde başı olarak verilen sözcüğün birinci anlamı '1. Sarkmak, aşağıya inmek. 2. Yük vb. şeyler bir yana eğilmek.', ikinci anlamı 'yükselmek, yukarı doğru çıkmak' biçimindedir. Clauson (1972: 77) ise sözcükle ilgili şu açıklamaları vermiştir: '(bir yerden) yükselmek, (bir yere) tırmanmak' anlamları erken dönemde yaygındır; ancak sözcüğün sadece bazı anlamlarının yaşadığı görülmektedir. Osmanlı Döneminde 'yükselmek, buharlaşmak vb.', Türkmencede 'üzerine tırmanmak, belli bir süreyi aşmak' anlamlarındadır. Kaşgarlı, ağ- ile aynı paragrafta, başka yerde kaydedilmediği gibi, 'yükselmek' anlamıyla bağlantılı olmayan bir anlam vermiştir. Erken zamanlarda kaydedilmemiş olsa da ăg- eyleminin 'at yükü veya bir çift terazi, bir tarafa yaslanmak vb.' anlamları modern zamanlarda görülmektedir. Bazı lehçelerde aynı zamanda 'bayılmak' anlamına gelen 
çağdaş sözcüğü ‘yükselmek' ile ilişkilendirmek zordur; fakat bu anlam, Kaşgarlı'nın ikinci anlamından doğmuş olabilir (Clauson, 1972: 77). Akar (2019: 27) ăgmak eyleminin günümüzde terazinin gözünün diğer gözdeki ağırlık sebebiyle aşă̆ı inmesi ve salıncakta karşılıklı oturanlardan birinin ă̆ırlı̆̆ıyla diğerinin yukarı çıkması anlamlarında kullanıldığını belirtmektedir. 'yukarı çıkmak' anlamının terazi ve tahterevallideki kullanımlarından dolayı anlam zıtlaşmasına uğradığını belirten Akar, eylemde terazinin bir gözünün veya tahterevallinin bir ucundaki kişinin yukarı çıkması tasvir edilmiş; fakat zamanla yukarı çıkan tarafa nispetle aşağı inen tarafın kastedildiğini ifade etmiştir. Clauson'da ayrı madde başında verilen ağ(II) 'rengi değişmek, solgunlaşmak, benzi atmak' anlamı Türkçe Sözlük’te yer almamaktadır (TS, 2011: 50).

\section{altıparmak (I) (II)}

Tietze (2002: 84), ‘altı renkli yolları olan bir kumaş’ ve ‘bir cins büyük balık’ anlamlarıyla sözcügü tek madde başında toplamıştır. Türkçe Sözlük'te ise sözcük, altıparmak (I) 'bir tür iri palamut balığı' altıparmak (II) '1. Aynı renkte altı yolu olan kumaş. 2. Bu kumaştan yapılan gelin giysisi.' anlamlarıyla iki ayrı madde başı olarak verilmiştir (TS, 2011: 108). Sözcügüün 'palamutun ikinci büyük cinsi' anlamı henüz yenidir. Her iki anlamda metaforla anlam genişlemesi söz konusudur. Palamut balığının türünün iri olması ve kumaşın altı yolunun olması altı parmağa benzetilmiştir. İki ayrı anlam alanına ait sözcük, çok anlamlı duruma gelmiştir. Anlam alanlarının farklı kavramları (tür adı ve giyecek) karşılaması neticesinde çok anlamlılıktan eş adlı duruma geçiş yapan sözcük Türkçe Sözlük’te iki ayrı madde başı olarak verilmiştir (TS, 2011: 108).

\section{basılmak (I) (II)}

Sözcüğün etkeni basmak Türkçe Sözlük’te tek madde başı olarak verilmişken edilgeni basılmak iki ayrı madde başı olarak verilmiştir (TS, 2011: 258). Clauson (1972: 370) basmak eylemini tek madde başında şu anlamlarla kaydetmiştir: 'bastırmak, ezmek, baskı yapmak, beklenmedik bir saldırı yapmak.' Tüm modern lehçelerde çok çeşitli temel ve genişletilmiş anlamları yaşamaktadır: 'yazdırmak, matbaada basmak, yayınlamak.' Türkçe Sözlük'te 'uygunsuz durumda yakalanmak' anlamıla kayıtlı basılmak (II) aslında 'beklenmedik bir saldırı, hamleye uğramak' anlamının genişleyerek ‘yasa dışı işlerle uğraşırken ilgili kişilerce yakalanmak' anlamını kazanması sonucu eș adlı duruma gelmiştir.

\section{biçim (I) (II)}

Sözcük, Eski Türkçede bıçım olarak geçmektedir. Sadece Osmanlıca ve Türkmencede biçim olarak geçen sözcüğün anlamları 'kesim, şekil, kalıp, tarz'dır. Hakaniye Türkçesinde 'dilim' anlamı da vardır: bir bıçım kağun (Clauson, 1972: 295). Türkçe Sözlük’te biçim (I) ve biçim (II) olarak iki ayrı madde başında eş adlı olarak verilen sözcük, anlam genişlemesi sonucunda çok anlamlı duruma gelip sonrasında iki ayrı sözcükmüş gibi eş adlılaştırılmıştır. Oysaki sözcüğün kökeni aynı olup bıç- şeklindedir. Zaten sözcügüün kökeni olan biçmek eylemi Türkçe Sözlük'te tek madde başında verilmiştir. Yani 'hasat' anlamı 'kumaşın belli kalıba göre kesilmesi’ vd. anlamları tek madde başında verilmiş olup sözcük, eş adlı olarak 
gösterilmemiştir. Türkçe Sözlük’e göre biçmek eylemi çok anlamlı; biç- eyleminden türetilen biçim adı ise eş adlı olarak kayıtlıdır. 'Kesmede örnek alma, kesme yöntemi, biçme eyleminde tutulan yol' anlamlarına gelen (Eyuboğlu, 2017: 89) biçim sözcügünün her iki madde başında da 'belli bir kalıba, ölçüye göre kesme eyleminden sonra ortaya çıkan şekil' anlamı söz konusudur. Edebiyat, bilişim gibi çeşitli disiplinlerde kullanılan sözcüğe yeni anlam alanları yüklenmiştir.

\section{bir bir (I) (II)}

Sözcük, Türkçe Sözlük’te bir bir (I) 'hepyek' bir bir (II) '1. Birer birer. 2. Ayrı ayrı. 3. Olduğu gibi, tam tamına, eksiksiz olarak.' iki ayrı madde başı olarak verilmiştir. Sözcüğün ikinci madde başı olan bir bir (II) anlamı tarihî metinlerde kayıtlıdır. hepyek anlamındaki bir bir (II) ise 'tavla oyununda zarların tek benekli yüzlerinin üste gelmesi durumu'ndaki Farsça kullanımının kod kopyalanma yoluyla Türkçeye kazandırılmasıyla oluşmuştur. Yine bazı iskambil oyunlarında veya spor müsabakalarında rakiplerin durumunu belirtmek için bir bir ifadesi kullanılmaktadır. Çok anlamlı olan sözcüğün bu anlamı Türkçe Sözlük’te yer almamaktadır.

\section{bitmek (I) (II)}

Sözcük geniş bir anlam yelpazesine sahiptir. Sözcüğün başlangıç noktası 'tamamlamak' anlamından oluşmuş gibi görünmektedir. Sözcük, 'sona gelmek, bitirmek' ve 'başlamaya hazır olmak' ile çeşitli özel kullanımlarıyla iki zıt yönde gelişme göstermiştir. 'bir bitkinin büyümesi', 'yaranın iyileşmesi', 'görev veya inşaatın tamamlanması', 'filizlenmek', 'var olmak', 'üretilmek', 'büyümek, gelişmek, uzatmak' gibi anlamları söz konusudur (Clauson, 1972: 298-299). Sözcük, aynı kökene sahip olup anlam zıtlaşması ve değişmesi sonucu iki farklı anlam alanı içinde gelişme göstermiştir. Sözcüğün bu anlamsal gelişimi bir şeyin bitmesi, yeni bir şeyin başlaması ya da bir şeyin başlaması diğer şeyin bitmesi felsefesiyle ilgili olabilir. Sona gelen bir şey, başlamaya hazırdır.

\section{boy (I) (II) (III)}

Türkçe Sözlük’te boy (I) ve boy (II) biçiminde geçen eş adlı sözcük, Clauson'da (1972: 296) en eski anlamının 'kabile' olduğu daha sonra yaygın olarak 'endam' anlamında kullanıldığı bilgisiyle tek madde başı ve çok anlamlı olarak açıklanmıştır. Clauson, boy boylamak sözünde geçen boy (III) sözcüğünü ise Türkçenin en eski zamanlarına, Bulgar Türkçesi dönemine kadar, dayandırmaktadır. Akar (2019: 64) boy sözcüğünün Eski Türkçe bod sözünden geldiğini; 'boy, kabile, sülale' ile ‘bir şeyin yerden yüksekliği' olmak üzere iki farklı anlamı olduğunu belirtmektedir.

Güncel Türkçe Sözlük’te yer almayıp Derleme Sözlügü̈'nde yer alan (https://sozluk.gov. tr/, Erişim Tarihi 17.03.2021) ve Tietze'de boy (IV) olarak geçen çemen otu anlamındaki sözcüğ̈̈n kökeniyse Farsçadır (Clauson, 1972: 384; Tietze, 2002: 304). 


\section{bozuk (I) (II)}

Sözcük, Clauson'da (1972: 390) 'bozuk, harap, yerle bir edilmiş vb.' bazen 'ahlaksı'' metafor anlamıyla tek madde başı, çok anlamlı olarak geçmektedir. 'Altı veya yedi telli bir çeşit müzik enstrümanı' anlamının 18. yüzyıl Osmanlı Türkçesinden itibaren görülmeye başlandığı bilgisi söz konusudur. Türkçe Sözlük’te (2011: 394) bozuk (II) ‘Türk halk müziğinde, bağlamadan biraz büyük ve meydan sazından küçük dokuz telli bir saz' anlamıyla kayıtlıdır. Tietze'de (2009: 308) bozuk III 'bağlamanın bir çeşidi', 'bu çalgıyı çalmak; (mecazi mânada) üzgün olmak, surat asmak (aslında bozuk I'i ima eden bir kelime oyunu)' anlamıyla kayıtlı madde başından yola çıkılarak aslında farklı görünen anlamların birbirleriyle ilişkili olduğu anlaşılmaktadır. Nişanyan ise halk müziğinde bir çalgı olan bozuk sözcüğünün muhtemelen ayrı bir sözcük olup ‘böğürmek' anlamındaki bozlamak eylemiyle ilgili olduğunu belirtmiştir (https://www.nisanyansozluk.com/?k=bozuk, Erişim Tarihi 24. 03. 2021).

\section{çakmak (I) (II)}

‘çakmak, 1şık, çakmaktaşı, çelik’ anlamlarına gelen sözcüğün (Clauson,1972: 408) Türkçe Sözlük’te çakmak (I) madde başında verilen bu anlamının yanı sıra çakmak (II) madde başında 'kuruduğunda kalın kabuk bağlayan kabarcıklarla beliren ve genellikle yüzde çıkan bir deri hastalığı' anlamı kayıtlıdır (TS, 2011: 484). Eyuboğlu (2017: 126) 'yüzde kalın kabarcıklar oluşturarak deriyi yaran bir sayrılık' anlamını çakmak (I) madde başının içinde vermiştir. Tietze'de (2002: 399) bu anlamı kayıtlı değildir. Sözcüğün çak- eyleminden, 'kök salmak, yer etmek, etki bırakmak' gibi anlam genişlemesiyle oluşan anlamları 'yüzdeki deri hastalığı' anlamını kazanmış olmasında etken olması muhtemeldir.

\section{çil (I) (II) (III)}

Clauson, sözcüğün iki anlamının olduğunu, metaforla anlam genişlemesinin söz konusu olduğunu belirtmiştir. Sözcük Clauson'da tek madde başında çok anlamlı olarak verilmiştir. 'benek ve dağ tavuğu' anlamları Eski Türkçeden itibaren (Clauson, 1972: 417) dilde yaşıyorken 'yeni ve parlak' anlamını içeren çil (III) madde başının daha yeni bir kullanımı olduğu söylenebilir (https://www.nisanyansozluk.com/?k=\%C3\%A7il, Erişim Tarihi 20.01.2021). Kaşgarlı bu sözcük için iki anlam vermiştir. İkinci anlam muhtemelen metaforla oluşmuştur. 'nokta, çil, benekli, cüzzamlı' birinci anlamları önceleri sadece Osmanlı Türkçesinde ve belki 'ekili bir alandaki münferit bir tarlanın sınırlarını tanımlayan bir sırt' anlamıyla Türkmen Türkçesinde yaşamaktaydı. Muhtemelen aynı sözcüğün 'benekli kuş' anlamından genişleyerek yeni bir 'çil' sözcüğü oluşmuştur. Yeni sözcüğün 'gri keklik, ela tavuk, Afrika ve Güney Asya'da bulunan başı veya boynu çıplak derisi olan, kekliği andıran büyük bir av kuşu (Francolin)' anlamları bulunmaktadır (Clauson, 1972: 417).

\section{çöğür (I) (II)}

Türkçe Sözlük’te (2011: 563) çögür (I) 'İri gövdeli, kısa saplı bir tür halk sazı.' çöğür (II) '1. Maydanozgillerden bir tür dikenli yaban bitkisi. 2. Tohumdan yetişmiş küçük fidan. 
biçiminde eş adlı olarak tanımlanan sözcük, Eren'e göre (1999: 99) 'iri gövdeli, kısa saplı bir tür halk çalgısı' olan anlamı 'ahlat ağacı ve dikenli ağaç' olarak kullanılan sözcükle ilişkilidir. Halk çalgısının üretildiği malzemenin ahlat ve dikenli ağaç olması ihtimalinden dolayı malzeme-ürün ilişkisiyle anlamsal bağlantı kurulmuş olmalıdır.

\section{dayak (I) (II)}

taya- eyleminden türetilen sözcük, 'destek, dayanak' anlamlarında olmasına karşın genellikle modern dillerde özellikle 'değnek, baston' anlamlarında kullanılmaktadır. 11. yüzyıl Hakaniye Türkçesinde 'asa, baston ve damadın gelinin hizmetine verdiği hizmetçi veya köle' anlamıyla da kullanıldığı belirtilmiş̧tir. Bu köleler gelinin atından inişine destek olmaktadır. $\mathrm{Bu}$ durum zenginlere ait bir gelenektir; böylece köle, gelinin mülkü olur (Clauson, 1972: 568). Bir şeye dayanmak, bir nesnenin insana fiziken destek olması anlamlarıla yola çıkan dayak sözcügünün anlamı genişleyerek 'asa, baston, koltuk değnekleri' gibi anlamlar kazanmıştır. Bunun yanı sıra sözcügün kullanım alanı genişleyerek zenginlerde gelinin attan inmesine destek olan hizmetçilere de bu ad verilmiştir. Türkçe Sözlük'te (2011: 600) dayak sözcüğünün asıl anlamının dayak (II) madde başında verildiği; dayak (I) madde başında ise 'Bir insanı veya bir hayvanı dövme işi, sopa, patak, kötek.' anlamı verilmiştir. Bu anlam Tarama Sözlüğ̈̈’nde yer almayıp yine sopa sözcüğünün işlev kazanmasıyla dile yeni bir anlam kazandırdığı görülmektedir. Eyuboğlu (2017: 170) bu durumu şu şekilde açılamaktadır: 'Kök anlamıyla dayanan, dayanılan nesne, anlam genişlemesiyle dayak atma, dayak denen nesneyle vurma.' Tarihsel süreçte çok anlamlı olan sözcügün bazı anlamları kaybolmuş; yakın zamanda da yine yeni anlamlar kazanmıştır. Bu durumda Türkçe Sözlük'ün, aslında çok anlamlı olan sözcügü eş adlı olarak belirlediği söylenebilir.

\section{dikilmek (I) (II)}

dikmek eyleminin edilgenidir. Yine etken eylem durumunda olduğu gibi Azeri, Türkmen ve Osmanlı Türkçelerinde oldukça geniş sahada anlamları söz konusudur. Hakaniye Türkçesinde ağacın dikilmesi anlamının yanı sıra bir şeyi dikey olarak kurmak anlamı bulunmaktadır (Clauson, 1972: 481). Sözcük aynı kökene dayanmakta olup çok anlamlıdır. Türkçe Sözlük'te dikilmek (I) ve dikilmek (II) ayrı madde başında verilmiş; lakin her iki madde başı dikme işi yapılmak biçiminde tanımlanmıştır (TS, 2011: 659). Birinci madde başında anıt, ağacın dikilmesi ve ikinci madde başında elbise dikilmesi örneklerinin verilmesiyle sözcük anlam bakımından ayrıştırılarak eş adlı durumda kaydedilmiştir.

\section{dikmek (I) (II)}

Clauson'da (1972: 476) çok anlaml, tek madde baş1 olarak verilen sözcügün temel anlam1 '-(bir şeyi bir şeye) eklemek'tir. Bir dizi çeşitli özelleştirilmiş anlamları mevcuttur: '(anıt taş) dikmek, bitki dikmek, dikiş dikmek vb.' Türkçe Sözlük'te '1. Bir cismi dik olarak durdurmak. 2. Yetiştirmek için bir bitkiyi toprağa yerleştirmek.' vd. anlamları dikmek (I) madde başında verilmişken 'biçilmiş veya yırtılmış kumaş, deri, yara vb.ni iğneye geçirilmiş iplikle 
tutturmak' anlamı dikmek (II)'de verilmiştir (TS, 2011: 661). Kökeni ve çıkış noktası aynı olan sözcük, anlam alanlarına göre eş adlı duruma gelmiştir.

\section{dil (I) (II) (IV)}

Dil sözcüğü, Türkçe Sözlük’te (2011: 664) dil (I) dil (II) dil (III) dil (IV) olarak dört ayrı madde başı biçiminde eş adlı olarak verilmiştir. dil (III) madde başı Farsçadan Türk diline geçmiş, eskimiş etiketiyle belirtilen 'gönül, yürek' anlamlarıyla kayıtlıdır. 'düşmanın durumunu öğrenmek için sorguya çekilmek amacıyla ele geçirilen tutsak' anlamındaki dil (IV) madde başı Türk Dil Kurumu elektronik sözlükte ayrı bir madde başı olarak verilmeyip dil (II) madde başının beşinci anlamı olarak çok anlamlı biçimde verilmiştir (https://sozluk.gov. tr/, Erişim Tarihi 20.03.2021). Tietze'de (2002: 550) bu anlamlara ek olarak 'anahtar, yazı kaleminin ucu; hayvanların boynuna asılan çanın içinde sallanan parça; klitoris; denize uzanan toprak ucu' anlamları kayıtlıdır. Bu anlamlar metafor yoluyla oluşmuştur ki Tietze de aynı madde başında söz konusu anlamlardan sonra 'şeklen dile benzeyen şeyler' açıklamasını yapmıştır. dil (III) madde başı Farsça iken, dil (I) dil (II) dil (IV) madde başları ise aynı kökene ait çok anlamlı bir sözcügün yeni madde başları olup eş adlı duruma gelmiştir. Clauson'da (1972: 489) çok anlamlı, tek madde başı olarak verilen sözcüğün asıl anlamı organ anlamındaki dildir. Organ adından dolayı metaforik olarak 'muhbir, bilgi, özellikle gizli bilgi, lisan, iletişim dili' anlamlarını kazanmıştır. Eyuboğlu (2017: 185-186) 'konuşulan dil, ağızdaki dil' anlamlarıyla sözcügü aynı madde başında vermiş; sözcüğün doğal ses, yansıma ses olma olasılığını ve ağızdaki dille konuşulan dil arasındaki bağlantının konuşma eyleminin ağızdaki dille sağlandığı ve bu durumun başka uluslarda da buna yakın olduğunu belirtmiştir.

\section{dokunma (I) (II)}

dokunma eylemsisi Eski Türkçede tokl- eyleminden türemiştir. Türkçe Sözlük’te (2011: 695) dokunma (I) 'Dokunmak (I) işi, temas', dokunma (II) 'Dokunmak (II) işi’ biçiminde iki ayrı madde başı olarak verilmiştir. Eyuboğlu ise (2017: 195) sözcüğe şu şekilde bir açıklama getirmiştir: 'Dokuma işleri, evlerde özel örme aygıtlarıyla yapılır, halı, kilim, cecim, giysilik gereçler dokunurken tokmak denen araçla yan yana, at başı gerilen ipliklere üstten vurulurdu. Böylece dokumak eylemi dokunan nesneye özel araçla vurularak yürütülürdü.’ Bu durumdan kaynaklı olarak çok anlamlı olan sözcük, Türkçe Sözlük’te eş adlı biçimde gösterilmiştir. tokl- eyleminden türemiş dokunmak ve dokunuş sözcüklerinde de çok anlamlılıktan eş adlılığa geçiş durumu söz konusudur.

\section{dokunmak (I) (II)}

Bu eylemin kökü, Eski Türkçede tokı- sözcügüdür. tokı- eyleminin 'vurmak, çarpmak dolayısıyla (bir düşmanı) dövmek, (bir kumaş) dokumak' biçiminde metaforlu ve genişlemiş anlamları mevcuttur. Muhtemelen atkı birleştirilmek için zaman zaman dövüldüğ̈̈̈nden anlamı genişlemiştir. Kuzeydoğu dil grupları hariç diğer modern lehçelerde genellikle ikinci ünlüsü -u- veya -a- olarak ve neredeyse her zaman 'kumaş dokumak' anlamıyla kullanılmaktadır 
(Clauson, 1972: 467). Sözcüğün asıl kullanımından ziyade metaforla kurulan ve anlam genişlemesiyle oluşan yeni anlamları kullanılmaktadır. Türkçe Sözlük’te (2011: 695) dokumak '1. Tezgâhta ipliği, çözgü ve atkı durumunda kullanarak kumaş yapmak. 2. En ince noktalarına kadar özen göstererek, emek vererek ortaya çıkarmak. 3. Ağacın yemişlerini sırıkla vurarak indirmek.' anlamlarıyla kayıtlıdır. dokunmak, dokumak eyleminin dönüşlülük eki almasıyla oluşmuştur. Genellikle 'çarpışmak anlamı olsa da aynı zamanda çeşitli deyimlerle dolu anlamları' da mevcuttur. Türkçe Sözlük’te (2011: 695) dokunmak (I) dokunmak (II) biçiminde iki ayrı madde başında eş adlı olarak verilmiştir. dokunmak (I) madde başında sözcüğün tarihî anlamı kayıtlı olmamakla birlikte anlam genişlemeleriyle yeni anlamları eklenmiştir. dokunmak (II) madde başında ise 'dokuma işi yapılmak: Halılar dokundu.' anlamı ve örneği bulunmaktadır.

\section{dokunuş (I) (II)}

dokunuş eylemsisindeki çok anlamlılıktan eş adlılığa geçme durumu, dokunma eylemsisindeki gibidir. Eski Türkçede tokl- eyleminden türeyen sözcük, Türkçe Sözlük’te dokunuş (I) ‘Dokunma (I) işi, temas’, dokunuş (II) ‘1. Dokunma (II) işi. 2. Dokunma ipliklerin çaprazlama biçimi.’ biçiminde iki ayrı madde başı dolayısıyla eş adlı olarak verilmiştir.

\section{el (II) el (III) $<$ èl}

Türkçe Sözlük’te (2011: 778) el (I) el (II) el (III) olarak üç ayrı madde başında verilen sözcügün organ $v d$. anlamındaki birinci madde başının tarihî süreçteki yazımı elig biçiminde olduğu, tarihsel süreçte diğer el sözcükleri ile eş adlı durumda olmadığı için bu çalışmada ele alınmayacaktır. el (II) 'Yakınların dışında kalan kimse, yabancı.' ile '1. Ülke, yurt, il. 2. Halk, ahali. 3. Oba, aşiret' anlamındaki el (III) madde başları değerlendirilecektir. Clauson'da (1972: 121-122) él biçiminde verilen sözcük tek madde başı ve iki anlamıyla çok anlamlıdır. Organ anlamındaki él/el, elig madde başına gönderilmiştir. Sözcüğün temelde orijinal anlamı 'bağıms1z bir yönetici tarafından düzenlenen ve yönetilen bir siyasi birim'dir. İngilizcede en uygun ve kısa ifadesi ülke, diyardır. Erken dönem metinlerinde genellikle ilişkili olduğu diğer politik terimlerle birlikte görülmektedir: kă̆an, bodun, töre, uluş, öge. Hakaniye Türkçesinden beri, görünüşe göre daha erken değil, bazı genişletilmiş anlamlar geliştirilmiştir. Sözcük, muhtemelen 'ev sahibinin kendine has alanı' metaforuyla avlu anlamını kazanmıştır. Tabir genellikle el kün biçiminde iki sözcük olarak heceleniyordu ki biraz sorunlu olan 'insan' anlamıyla bu ifade ilk kez Kutadgu Bilig'de belirlenmiştir. Kitab'ül-İdrak’te 'güneş' anlamıyla verilmiş kün teorisi, kesinlikle mantıklı değildir. En makul açıklama, ikinci hecedeki -gün ekinin topluluk soneki olduğu ve bir sözcük şeklinde elgün olarak yazılması gerektiğidir. él/el/il 'ülke, il; insan, topluluk (özellikle yabancıların aksine kişinin kendi halkı) ve (daha az sıklıkta) barış’ anlamlarına gelmektedir. elgün aynı zamanda 'müttefikler ve yardımcılar' anlamında ikileme olarak kullanılmaktadır. el tek başına bu anlamı verirken gün vermemektedir. 14. yüzyıl Osmanlı Türkçesinde hem $e l$ hem $i l$ olarak telaffuz edilen sözcügün 'ülke, devlet, il' anlamlarının yanı sıra 'insan, özellikle diğer insan'; 'barış, huzur içinde, dostça' anlamları görülmektedir. O halde el (II) madde başı, Türkçenin tarihî seyri içinde oluşmuş, böylece sözcük çok anlamlı duruma gelmiştir. Sözcük, Türkçe Sözlük’te eş adlı olarak verilmiştir. 


\section{gen (I) (II) (III)}

Türkçe Sözlük’te (2011: 925) gen (I) (II) (III) (IV) dört ayrı madde başında eş adlı olarak verilen gen sözcüğünün, gen (IV) Türkçe Sözlük’e göre Fransızca, Tietze’ye göre (2009: 127) Almanca olan madde başı bu çalışma dışındadır. Geriye kalan gen (I) (II) (III) madde başlarıyla ilgili sınıflandırma yapmak güçtür. Zira gen (II) 'Üçgen, dörtgen vb. geometri terimlerinde 'kenarlı' anlamıyla kullanılan bir söz.' anlamı ve 'Bir süre sürülmeyerek boş bırakılmış (tarla).' anlamındaki gen (III) madde başlarını belirli bir kategoriye yerleştirmek problemlidir. Clauson'da (1972: 724) bu iki anlamı, Tietze'de ise (2009: 127) gen (II) sözcüğünü içeren bir madde başı bulunmamaktadır. Tarama Sözlüğü ve Eyuboğlu (2017: 275) 'boş yer, el sürülmemiş, sürülmemiş, işlenmemiş tarla' anlamını 'geniş, enli' anlamıyla ilişkilendirmiştir. O halde gen (I) ve gen (III) madde başlarının çok anlamlılıktan eş adlılığa geçiş yaptığı söylenebilir. gen (II) geometri terimi ise muhtemelen Batı dillerinden alıntılanmış ödünç sözcüktür. Clauson'da (1972: 724) yer alan ken 1, kend madde başına yönlendirilmiş ve kén 2 ise 'bir mekânın arkasında ve bir zamanın sonrasında' anlamlarında verilmiştir. $\mathrm{Na}$ zal $n / \mathrm{y} /$ ile ayrı madde başında verilen kéy ise 'geniş, enli' anlamıyla kayıtlıdır.

\section{güç (I) (II)}

İngilizcede 'strength' sözcüğü, pek çok anlam katmanına sahiptir. Öncelikle insan ve hayvan için kullanılır ve zor bir şeyi yapmanın (örneğin ağır bir ağırlığı kaldırmak veya çok sert bir şeyi kırmak) fiziksel gücü veya dış kuvvete direnme, dayanma anlamına gelir. Aynı zamanda 'zihin gücü' ifadesinde olduğu gibi zihinsel nitelikler için de kullanılabilir ve 'Bir zincirin gücü en zayıf halkasında yatar.' ifadesinden görüldüğü üzere cansız nesnelere uygulanabilir. strength sözcügündeki anlamları içeren Türkçedeki sözcük küç’tür (Clauson, 1962: 93-94).

güç < küç sözcüğü Clauson'da (1972: 693) iki madde başı olup birinci madde başındaki küç 'fiziksel ve soyut anlamda güç' ve birtakım anlam genişlemeleriyle 'baskı, şiddet, iş, önemli işler, zorlama, gayret' anlamlarıyla kayıtlıdır. İkinci madde başı ise soru işaretlidir. İkinci madde başındaki küç 'susam tohumu' anlamına gelmekte ve Türkçe Sözlük’te bu anlam yer almamaktadır. Çok anlamlı olan sözcüğün genişleyen anlamları, Türkçe Sözlük’te (2011: 994) iki ayrı madde başı olarak ayrılmıştır. Tietze (2009: 198) sözcüğün genişleyen anlamlarını 4 ayrı madde başında vermiştir.

\section{günlük (I) (II)}

günlük< künlük 'bir gün vb. günlük işler' anlamlarına sahip sözcük, 'tütsü taneleri, güneşlik, güneş şemsiyesi, günlük ödeme, buhur, tütsü’ gibi yeni anlamlar kazanmıştır. Osmanlı Türkçesi dönemi metinlerinde 'güneşlik, güneş şemsiyesi' anlamları görülürken 18. yüzyılda bu anlamlara 'buhur, tütsü’ anlamları eklenmiştir. Hala güncel olan 'tütsü' anlamının açık bir nedeni yoktur (Clauson, 1972: 732). 'Bir çeşit ağacın reçinesinden yapılan tütsü maddesi' anlamını veren Tietze (2009: 212) sözcügü günlik / günlük biçiminde eş adlı olarak üç ayrı madde başında vermiştir. Türkçe Sözlük (2011: 1009) sözcüğü iki madde başı olarak verip 
herhangi bir köken belirtmemiştir. Eren (1999: 167) günlük (II) sözcüğünün kökeninin bilinmediğini belirtmiştir. Sözcüğü Eyuboğlu (2017: 303) Sanskritçe kunduruka, Nişanyan da Farsça ve Sanskritçe kundurak sözcügüule ilişkilendirmişlerdir (https://www.nisanyansozluk.com $/$ ?k=g\%C3\%BCnl\%C3\%BCk, Erişim Tarihi 12.02.2021).

\section{öz (I) (II)}

Öz sözcüğü Türkçe Sözlük’te (2011: 1865) öz (I) öz (II) öz (III) olarak üç ayrı madde başında verilmiştir. Üç ayrı madde başında verilen tüm anlamlar Eren'de (1999: 318) tek madde başında çok anlamlı olarak verilmiştir. Eyuboğlu'nda (2017: 540) da tek bir öz madde başı söz konusudur. Clauson'da (1972: 278) iki ayrı öz madde başı bulunmaktadır. Birinci öz kendi içinde iki anlam içermekte olup Türkçe Sözlük’teki öz (I) ve öz (II) madde başlarına tekabül etmektedir. Clauson'daki ikinci madde başı 'vadi' anlamında olup Türkçe Sözlük'teki '1. Dere, çay. 2. Sulak, verimli yer.' anlamlarındaki öz (III) madde başıyla eşleşmektedir ve bu çalışmanın dışındadır². Clauson, sözcüğü şöyle tanımlamıştır 'temelde somut bedenin aksine, insan kişiliğinin 'ruhunun' soyut kısmı, dolayısıyla basitçe bir birleşik sözcükle karşılanmaktadır: etöz.' 'kendi' anlamını da taşımaktadır. İkinci anlamı ise 'akraba, komşu, yoldaş’ anlamlarıyla kayıtlıdır. Bu durumda sözcüğün semantik ilişkisini şöyle açıklamak mümkün: Kişinin kendi canına, ruhuna yakın olan kişileri seçme durumu öz'lükle ilgilidir. İnsanın kendi benliğine [öz (I)] yakın olan kişi özü' [öz (II)]dür, ruhuna yakın olan yoldaşıdır.

\section{sağ (I) (II)}

să̆ sözcüğü en erken dönemlerde 'saf tereyağı' bu yüzden daha çok 'sağlam, sağlıklı' anlamlarına gelmektedir. İlginç metaforik bir durumla sadece Oğuz gruplarında 'sol olmayan, sağ' anlamına gelmektedir. Sözcükte sağ, sax, sav, saw, so:, su: gibi birtakım ses değişiklikleri görülmektedir. Oğuzlarda 'iyi, sağlıklı, sağlam, saf ve lezzetli su’ anlamlarıyla birlikte 'solun zıtt1, sağ' anlamı da mevcuttur. Osmanlı döneminde 'güvenilir, dürüst, namuslu, saf’ anlamlarıyla sözcüğün anlamı genişlemiştir. Kaşgarlı, solun karşıtı să̆ el kavramını Oğuzların bildiğini, Oğuzlar dışındaki Türklerin să̆ yerine oy kullandıklarını belirtmiştir (Cluason, 1972: 803). Să̆ sözcüğünün ‘yön ve nitelik' olarak iki ayrı anlam doğrultusunda gelişmesi olağandır (Eyuboğlu, 2017: 571). Türkçe Sözlük’te sağ (I) '1. Vücutta kalbin bulunduğu tarafın karşısında olan, sol karşıtı. 2. Bu taraftaki yön. 3. Ekonomi ve siyasette gelenekçi (görüş). 4. Boksta sağ yumrukla vuruş.’ sağ (II) ‘1. Sağlam, esen. 2. Yaşamakta olan. 3. Katkısız’ anlamlarıyla kayıtlıdır (TS, 2011: 2003). sağ sözcüğü aslında tarihsel süreçte eş adlıdır. Lakin tarihî süreçteki eş adlıları günümüze ulaşmamıştır. 'Yünün işlendiği çubuklar' anlamına gelen sağ (II) ile 'akıl, zekâ, sağduyu' anlamlarındaki sağ (III) madde başları (Clauson, 1972: 803) Türkçe Sözlük’te yer almamaktadır.

\section{sormak (I) (II)}

Türkçe Sözlük (2011: 2142) ve Clauson'da (1972: 843-844) iki ayrı madde başı olarak verilen sözcüğün anlam sıralanışı, kullanım sıklıklarına göre belirlenmiş olup Türkçe Sözlük’te sormak (I) '1. Birine soru yönelterek herhangi bir konuda bilgi istemek, sual etmek. 2. Bir işin 
sorumluluğu kendisinde olmak, bir işten sorumlu bulunmak.' sormak (II) 'Dudakları uzatıp soluğu kuvvetle çekerek emmek.' sıralanmıştır. Clauson'da ise anlam sıralanışı Türkçe Sözlük'ün tam tersidir. Akar (2019: 245) her iki eylemin birbiriyle anlam ilişkisi olduğuna dikkat çekmiştir: em- anlamındaki eylem, 'annenin göğsünden süt talep etmekken soru sorma anlamında da herhangi bir konuda ihtiyaç duyulan bilgiye yanit bekleme, isteme söz konusudur. Çocuğun annesinin göğsünden süt emerken içinde olduğu talep ve beklenti durumu soru soran kişi için de geçerli olduğundan iki eylem arasında semantik bir bağ söz konusu olup sözcük, aynı kökene dayanmaktadır. Çok anlamlı olan sözcük zamanla eş adlı duruma geçmiştir.

\section{ters (I) (II)}

Geniş çaplı, pejoratif anlamlara sahip sıfat/zarf olarak kullanılan bir sözcüktür. Orijinali muhtemelen 'yanlış' olmakla birlikte aynı zamanda 'hasım, zıt, aksi, rahatsız edici' vb. anlamlara sahiptir. Uygurcada sık sık tétrü sözcügüyle ikileme olarak kullanılmaktadır. Genellikle ters, ara sıra teris olarak geçmektedir. Osmanlı Türkçesi döneminde ortaya çıkan 'gübre, hayvan dışkısı' ikinci anlamı, büyük ihtimalle metaforla oluşmuştur (Clauson, 1972: 553). Sözcük 'gübre, tezek' anlamıyla Nechü'l Ferâdîs'te de geçmektedir (Ata, 1998: 422). Eyuboğlu (2017: 657) da sözcüğün anlam genişlemesiyle 'geri dönmek, dışkılık çıkarmak, ayakyoluna gitmek’ gibi yeni anlamlar kazandığını belirterek sözcüğü aynı kökene dayandırmıştır

\section{terslemek (I) (II)}

ters kökünden $+l A$ işlek olan addan eylem yapım ekiyle terslemek eylemi türetilmiştir. 'bir kimseye gönül kırıcı, sert söz söylemek veya gönül kırıcı davranmak, azarlamak' (TS, 2011: 2333) anlamındaki terslemek (I) Tarama ve Derleme Sözlüğü’nde yer almamaktadır. Daha yeni; ama sık kullanılan bu soyut anlam, ters (I) sözcüğünün temel anlamından türemiştir. ters (I) sözcüğünden metafor yoluyla ortaya çıktığı varsayılan ters (II) sözcüğünden türetilen terslemek (II) ise Tarama Sözlüğü'nde 'abdest bozmak', Derleme Sözlüğü’nde 'tarlay1 gübrelemek, pislemek’ (https://sozluk.gov.tr/, Erişim Tarihi 26.03.2021) anlamıyla kayıtlıdır.

\section{uçuk (I) (II)}

Sözcük, Çağatay Türkçesindeki 'ateş noktaları' uçuğ/uçuk ile bağlantılı olup metaforik olarak 'gözün içinde büyüyen arpacık, it dirseği' anlamlarını kazanmıştır. Osmanlı Türkçesi döneminde sözcüğe 'epilepsi (sara) hastalığı' anlamı eklenmiştir. uçğuk ise muhtemelen $u c ̧ u k$ sözcügünün daha önceki biçimi olup 'nezle, soğuk algınlığı' anlamlarına gelmektedir (Clauson, 1972: 23). uç- eyleminin anlam genişlemesiyle 'rengi gitmiş, solup sararmış ve belirmiş, kabarmış’ anlamlarını kazandığı görülmektedir (Eyuboğlu, 2017: 681). Türkçe Sözlük’te (2011: 2408) uçuk (I) uçuk (II) iki ayrı madde başı olarak verilmiştir.

\section{uğur (I) (II)}

Türkçe Sözlük’te üç ayrı madde başı olarak verilen sözcük (TS, 2011: 2412) anlam genişlemeleri sonucunda yeni anlamların birbirinden uzaklaşması sonucu eş adlı duruma gelmiştir. 
Sözcük anlamsal olarak belirsiz olmakla birlikte hem 'zaman' hem de 'neden, amaç, gaye' anlamlarına gelmektedir. Hangisinin en başta olduğunu söylemek güçtür. 'zaman' 'doğru zaman, hayırl, talihli zaman' anlamlarına dönüşerek bu yüzden bugün 'iyi şans' anlamıyla birinci sırada yerini almıştır. Sözcük 'firsat, kutsama ve mutluluk, kısmet, baht, kader, yön, amaç, seyahat' anlamlarına sahiptir (Clauson, 1972: 89). Sözcüğün asıl anlamı 'yol, çı̆̆ı̆' olup 'insanlara hayır, bereket, güzellik getirdiğine inanılan durum' vb. anlamlarıyla çok anlamlıdır (Akar, 2019: 269). Akar'ın sözcüğün asıl anlamı olarak belirttiği 'Hedef, amaç, erek, gaye, yol' anlamları Türkçe Sözlük’te uğur (II) madde başında verilmiştir. Sözcüğün temel anlamı kullanım sıklığ bakımından günümüzde daha geridedir. Eyuboğlu da (2017: 684) sözcüğün 'bolluk, yücelik' gibi anlamları olup çok anlamlı olduğunu belirtmiştir. uğur (III) madde başı ise 'Ön veya yan' anlamıyla tanımlanmış olup halk ağzında kullanılmaktadır (TS, 2011: 2412).

\section{uz (I) (II)}

Sözcüguün anlamı 'yetenekli usta, becerikli' ve genişletmeyle cansız nesneler için 'mükemmel, sağlam' durumda anlamlarına gelmektedir. Bununla birlikte çok genişletilmiş anlamları mevcuttur. Bazı cümlelerde 'tamamen' anlamından daha fazla bir şey ifade etmediği görülmektedir. Sözcük 15. yüzyıl Çağatay sahasında 'etkili, tecrübeli, yetenekli' gibi anlamlar kazanmıştır. Aslında 'yetenekli' olan anlamı 15. yüzyıldan itibaren 'zeki, akıllı, uygun, münasip, elverişli’ anlamlarına dönüşmüştür (Clauson, 1972: 277). Tarama Sözlüğü’nde (TaS, 2009: 4048) birinci anlamı 15. yüzyıldan itibaren kazanılan yeni anlamı olan 'ustaca, münasip, uygun, muvafik, doğru', ikinci anlamı ise 'usta, mahir, hazık, tecrübeli, dikkatli, uyanık' olarak verilmiştir. Eyuboğlu (2017: 695) sözcüğü tek madde olarak 'us, öz, genişleme, uzama, erk, yetme, beceri, başarı, açılma, gevşeme' anlamlarıyla vermiştir. Türkçe Sözlük'te ise uz (I) '1. iyi, güzel. 2. işe yatkın, becerikli, mahir'; uz (II) 'Masallarda az gittik uz gittik, dere tepe düz gittik tekerlemesinde 'uzak' anlamında kullanılan bir söz' olarak geçmektedir (TS, 2011: 2433). Masallardaki tekerlemede geçen uz (II) sözcüğünün anlamının tarihî metinlerde geçen 'uygun, doğru, münasip' anlamlarında kullanılmış olma ihtimali güçlüdür. Zira az yol gittik fakat makul, münasip, doğru, uygun bir biçimde ilerledik anlamı tamamlayıcı bir ifade durumundadır.

\section{yaş (I) (II)}

Temel anlamda 'taze ve nemli' anlamlarına gelmektedir. Bu temel anlam, yeni genişletilmiş anlam anlamlarına gelişmiştir. Birincisi 'yeşil sebzeler' için 'tazelik' ikincisi '1slaklık ve gözyaşı' ile kullanılan 'nemli' ve belki de 'her taze yıl', 'birinin yaşamından bir y1l' anlamları ortaya çıkmıştır. İnsanın yaşı anlamına gelen sözcük başka bir sözcük olabilir. Son anlamın daha erken olması için hiçbir makul şüphe bulunmamaktadır (Clauson, 1972: 975). Eyuboğlu da (2017: 735) yaş sözcüğünün çok anlamlı bir kökene dayandığını belirtmiştir. 'yeşil, ıslak, aydınlık, gizli, saklı, örtmek, yaşamak, gelişmek, ışımak' gibi çok değişik anlamlarda kavramların türemesine olanak sağlamış kök, 'yaş, taze, sebze, yeşillik, kişinin yaşadığ 1 süre, gözden akan yaş, taze, yeşil, ot, yaşam, gözyaşı, yıkım' anlamlarıyla tanımlamıştır. 
Türkçe Sözlük’te (2011: 2545) yaş (I) 'zaman vd.', yaş (II) ‘nemli, gözyaşı vb.' anlamlarıyla tanımlanmıştır. Tarama Sözlüğü’nde de sözcüğün '1. taze. 2. deniz' anlamlarının (https:// sozluk.gov.tr/, Erişim Tarihi 26.03.2021) yer alıp insan ömrüyle ilgili kullanımının olmaması, Clauson'un zamanla ilgili anlamın daha erken olamayacağına dair görüşünü doğrular niteliktedir.

\section{yaşlı (I) (II)}

Tarama ve Derleme Sözlüğü’nde yer almayan sözcük (https://sozluk.gov.tr/, Erişim Tarihi 26.03.2021) Türkçe Sözlük’te (2011: 2548) yaşlı (I) '1. Yaşı ilerlemiş, kocamış, ihtiyar (kimse). 2. Uzun yılları geride bırakmış.' yaşlı (II) 'Yaşla dolmuş (göz).' anlamlarıyla kayıtlıdır. Sözcüğün temel anlamı aslında yaşlı (II) madde başındaki anlamla ilgilidir. Sözcüğün anlam genişlemesi, sözcüğün kökü olan yaş (I) (II) madde başlarıyla aynı şekildedir. Türkçenin tarihî sürecinde yaşı ilerlemiş anlamında kullanılan koca, karı gibi eskicil sözcükler kullanımdan düşmüş, yerini Arapçadan ödünçlenen ihtiyar ile kişinin yaşadı̆̆ s süre anlamını taşıyan yaşlı (I) sözcüğüne bırakmıştır.

\section{yazı (I) (II)}

Türkçe Sözlük'te 'düz yer, ova, kır' anlamındaki yazı (II) halk ağzında kullanılmakta ibaresiyle yer almaktadır (TS, 2011: 2560). Sözcügün temel ve tarihî anlamı yaz (II) günümüzde ölçünlü dilde kullanımdan düşmüş, ağızlarda yaşamaya devam etmiştir. 'geniş açık bir ova’ anlamına gelen sözcük genellikle coğrafi adlarla kullanılmaktadır: Şantuy Yazı. Sözcük, Türkçenin diğer tarihî lehçelerinde de bu anlamıyla kayıtlıdır. Osmanlı Döneminde 'büyük ova, çöl' anlamlarına sahiptir (Clauson, 1972: 984). 'düz yer, ova' anlamına gelen sözcük Anadolu'da yer adı olarak sık sık kullanılmaktadır. Sözcük, ‘yaymak, açmak' anlamındaki yaz- eylem kökünden türemiştir (Eren, 1999: 448). Gerçek anlamı 'ova, yayılma, açılma yeri, geniş düzlük' olan sözcüğün anlamı genişleyerek 'kalemle yazılan' anlamı söz konusu olmuştur (Eyuboğlu, 2017: 743).

\section{yazmak (I) (III)}

Clauson'da (1972: 983-984) üç ayrı yaz- madde başı vardır; lakin yazmak (I) ve yazmak (II) Türkçe Sözlük’teki yazmak eyleminin anlamlarıyla ilgili değildir. Birinci yaz- 'bir şeyi daha basit bir forma indirgemek, çözmek, açmak, eritmek' ikinci yaz- 'bir hata ya da ihmal dolayısıyla daha kesin olarak kişinin yolunu kaybetmesi, suç işlemek, günah işlemek’ anlamlarını içermektedir. Son yaz- madde başı ise 'yazı yazmak' anlamındaki sözcügün temelde Oğuzlarda görüldüğü, ama çok eski olduğu bilgisi kaydedilmiştir. Erken dönem Türkçesinde sözcük 'çizmek, boyamak' anlamlarını, biti- eylemi ise (Oğuzlar'da 11. yüzyıldan itibaren yaz-) 'yazı yazmak' anlamını içermektedir. Eren de (1999: 447) Clauson gibi yaz- sözcüğü ile yay-sözcüğü arasındaki ilişkiyi detaylı bir biçimde vermiştir. Eyuboğlu (2017: 744) yazmak eyleminin yaymak ile ilişkisinden bahsetmiştir. Yazı yazmanın da gerçekte yaymak anlamın- 
da, yazı denen sözcük araçlarını bir nesnenin üzerine dizerek arka arkaya getirmenin yaymak eylemi olduğunu, anlam genişlemesiyle yazmanın yalnız yazı için geçerliliğini oysa kökün değişmediğini belirtmiştir.

\section{yordurmak (I) (II)}

yormak eylemine - $D U r$ ettirgenlik eki getirilerek eylemin geçişli durumu devam ettirilmiştir. Eylemde yormak eylemini başkasına yaptırma anlamı vardır. 'yorumunu yaptırmak, yorumlanmasını sağlamak' anlamı zamanla 'bitkinlik anlamında yorulmasını sağlamak' anlamıyla çok anlamlı olmuştur. Türkçe Sözlük'te 'yorulmasını sağlamak' anlamıyla yordurmak (I) madde başını oluşturmuştur (TS, 2011: 2607).

\section{yormak (I) (II)}

'Fiziksel olarak açmak, metaforik olarak (bir rüyayı) yorumlamak, (bir öğreti vb.) açıklamak' anlamlarına gelen sözcük, erken dönemde tartısmasız -ö- olarak kullanılmaktadır. Ama Kutadgu Bilig'in Fergana ve Kahire nüshalarında bazen -o- şeklinde hayatta kalır. Viyana nüshasında yine -ö- olarak geçer. Azeri, Türkmen ve Osmanlı Türkçelerinde yor- olarak '(rüyaları) yorumlamak, (geleceği) tahmin etmek’ anlamlarında kullanılır (Clauson, 1972: 955). Sözlüklerde yor- köküyle başlayan sözcüklerde 'devinme, hareket' anlamı saklıdır. Yormak 'bir nesneyi, bir düşü alabildiğine ileri götürmek, genişletmek, yürütmek' karşılığındadır. 'Çok devinmeden, eylemden, işten dolayı bitkin düşürmek, gücünü azaltmak, direncini eksiltmek, yorgun duruma getirmek' anlamlarını anlam genişlemesi yoluyla kazanmıştır (Eyuboğlu, 2017: 764). Böylece anlam genişlemesi yoluyla çok anlamlı duruma gelen sözcük, ikinci bir yor- eylemini ortaya çıkarmıştır. Ortaya çıkan bu yeni eylem kazandığı yeni mecaz anlamlarla kökteş olduğu sözcükten uzaklaşmış, yeni bir madde başı oluşturmuştur. Sözlükte kullanım sıklı̆ı̆ından dolayı birinci madde başı gücünü azaltmak anlamındaki yormak (I) olarak geçmektedir (TS, 2011: 2608). yormak (I) anlamı Tarama Sözlüğü'nde (TaS, 2009: 4672) yormak 'alıkoymak' anlamındadır. Yorşumak madde başı 'yorgun düşmek' anlamında olup 18-19. yüzyıl örnekleriyle tanıklanmıştır. Sözcüğün bu anlamı kazanması Osmanlı Türkçesinin son dönemlerinde olmas1 muhtemeldir. Kutadgu Bilig'de sözcük 'tabir etmek, yormak' anlamında verilmiş̧ir (Arat, 1979: 552). Eski Türkçede geçen yorgun argin ikilemesinde ar- eylemi önce 'mahvolmak' daha sonra 'yorulmak' anlamıyla kullanılmaktadır (Akar, 2019: 316). İkileme yine hareket, devinim sonucuyla birlikte 'yorulmak, yorgun düşmek' anlamına gelmektedir.

\section{yorulmak (I) (II)}

yormak eyleminden türetilmiş yorulmak eylemi Türkçe Sözlük'te yorulmak (I) 'yorgun duruma gelmek' ve yorulmak (II) 'bir sebebe bağlanılmak, yorumlanmak' anlamlarıyla kayıtlıdır (TS, 2011: 2608). Sözcükte tarihî süreç içinde 'Çok işten, devinmeden, eylemden dolayı kendi kendini yormak' (Eyuboğlu, 2017: 764) anlamı söz konusu olmuştur. Sözcüğün asıl anlamının kullanımı son zamanlarda azalmıştır. 


\section{Sonuç}

Türkçe Sözlük’te (I) (II) (III) biçiminde eş adlı durumda olduğu belirtilerek madde başına alınmış 40 sözcük genel tarama modeliyle tespit edilmiştir. Bu verilerin, tarihî ve etimolojik sözlüklerden yararlanılarak tarihsel yolculukları boyunca birtakım nedenlerden ötürü çok anlamlı durumdan eş adlılığa geçtikleri belirlenmiştir. Aslında bu 40 sözcük, aynı kökene ait sözcügün anlam birimlerinin zamanla birbirinden uzaklaşarak yeni sözlük birimleri oluşturulmuş versiyonlarıdır. Türk dili gibi diğer dillerde de çok anlamlılık ve eş adlılık kavramları belirli alanlarda ilişkili ve iç içedir. Çok anlamlılığın ve eş adlılığın oluşum nedenlerinden birisi de bir diğeridir. Bu bağlamda Türkçenin söz varlığında yer alan bazı eş adlı sözcüklerin oluşum nedenlerinin çok anlamlılıktan kaynaklı olduğunu söylemek yerinde olacaktır.

\section{Notlar}

1 Çalışmada, Türk Dil Kurumu Türkçe Sözlük TS olarak kısaltılmıştır.

2 Akar (2019: 228) öz sözcügünün tarihsel gelişimini şu şekilde açıklamıştır: Halk ağızlarında 'küçük ırmak, çay’ anlamlarına gelen sözcük, Köktürkçedeki 'ırmak, nehir' anlamına gelen ögüz sözcüğüyle ilişkilidir (ögüz $>$ öğüz > ööz > öz).

\section{Kaynakça}

Ahanov, K. (2008). Dil biliminin esaslarl (M Ceritoğlu. Akt.) Ankara: Türk Dil Kurumu. Akar, A. (2019). Düşünen Türkçe. İstanbul: Ötüken.

Akıncı S. ve Ünder H. A. (2019). Klasik mantık. Eskişehir: Anadolu Üniversitesi.

Aksan, D. (2009). Her yönüyle dil ana çizgileriyle dilbilim. Ankara: Türk Dil Kurumu.

Arat, R. R. (1979). Kutadgu Bilig III indeks (K. Eraslan, O. F. Sertkaya, N. Yüce. Haz.) İstanbul: Edebiyat Fakültesi.

Ata, A. (1998). Nechü'l-feradis III dizin-sözlük. Ankara: Türk Dil Kurumu.

Caferoğlu, A. (2011). Eski Uygur Türkçesi sözlüğ̈̈. Ankara: Türk Dil Kurumu.

Clauson, G. (1962). The concept of "strength" in Turkish. Németh Armağanı, Say1 191, Ankara: Türk Tarih Kurumu, 93-101.

Clauson, Sir G. (1972). An etymological dictionary of pre-thirteenth-century Turkish. London: Oxford University.

Eren, H. (1999). Türk dilinin etimolojik sözlü̆̆̈̈. Ankara: Bizim Büro.

Erkınay Tamtamış, H. K. (2021). Türkçede eş adlılık. Akademik Dil ve Edebiyat Dergisi, 5 (1), 619653. DOI: 10.34083 /akaded.899583.

Eyuboğlu, İ. Z. (2017). Türk dilinin etimoloji sözlüğü. İstanbul: Say.

Günay, V. D. (2007). Sözcükbilime giriş. İstanbul: Multilingual.

Hartmann, R.R.K., James, G. (1998). Dictionary of lexicography. London: Routledge.

Hengirmen, M. (2009). Dilbilgisi ve dilbilim terimleri sözlüğ̈̈. Ankara: Engin.

İmer, K., Kocaman, A., Özsoy, A. S., (2011). Dilbilim sözlüğü. İstanbul: Boğaziçi Üniversitesi. Karaağaç, G. (2013). Anlam (Anlam bilimi ve iletişim). İstanbul: Kesit. 
Karasar, N. (2012). Bilimsel araştırma yöntemi kavramlar-İlkeler-Teknikler. (23. bs.) Ankara: Nobel.

Palmer, F.R. (2001). Semantik yeni bir anlambilim projesi (R. Ertürk. Çev.) Ankara: Kitâbiyât.

Tarama Sözlüğü: XIII. yüzyıldan beri Türkiye Türkçesiyle yazılmış kitaplardan toplanan tanıklarıyla (2009). Ö. A. Aksoy, D. Dilçin (Haz.). (3. bs.), Ankara: Türk Dil Kurumu.

Tietze A. (2002). Tarihi ve etimolojik Türkiye Türkçesi lugatı I A-E. İstanbul: Simurg.

Tietze A. (2009). Tarihi ve etimolojik Türkiye Türkçesi lugatı F-J. Wien: Österreichische Akademie der Wissenschaften.

Toklu, O. (2003). Dilbilime giriş. Ankara: Akçağ.

Türkçe Sözlük (2011). (Ş. H. Akalın vd., Haz.). (11. bs.), Ankara: Türk Dil Kurumu.

Ullmann, S. (1970). Semantics an introduction to the science of meaning. Oxford: Alden.

Üçok, N. (2004). Genel dilbilim (Lengüistik). İstanbul: Multilingual.

\section{Elektronik kaynaklar}

Türk Dil Kurumu, Erişim Tarihi 17.03.2021, https://sozluk.gov.tr/

Nişanyan S., Erişim Tarihi 20. 01. 2021, https://www.nisanyansozluk.com/?k=\%C3\%A7ap

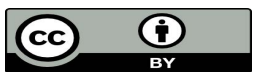

Bu eser Creative Commons Atıf 4.0 Uluslararası Lisansı ile lisanslanmıştır. (This work is licensed under a Creative Commons Attribution 4.0 International License). 